Committee, left a vacancy which was hard to fill. It has been filled, however, by the unanimous election of Sir Harold Hartley, chairman of the British National Committee. By invitation of the American Government, the third World Power Conference will be held in Washington, U.S.A., on September 7-12. The subject matter will be National Power Economy. This will be the third plenary meeting of the World Power Conference, previous plenary meetings having been held at Wembley (1924) and Berlin (1930). There have also been a number of sectional meetings with more limited programmes. The Chemical Engineering Congress meeting in London next week, to which reference is made on p. 1018, is such a sectional meeting. The International Commission on Large Dams of the World Power Conference will be held at Washington concurrently with the third World Power Conference. Work has been continued during 1935 on investigating special cement for use in the construction of dams, and in connexion with the establishment of the international statistical register of large dams.

\section{Seventh International Congress of Refrigeration}

UNDER the auspices of the International Institute of Refrigeration, which has its headquarters in Paris, a congress reflecting all sides of the practice and theory of refrigeration, to which the Governments of more than fifty countries are sending official delegates, is being held at The Hague on June 16-27. The British party visiting Holland, numbering about eighty persons, and headed by Dr. Ezer Griffiths, president of the British Association of Refrigeration, is the largest overseas delegation to the Congress. By the co-operation of Lord Rutherford and Prof. F. A. Lindemann, several well-known scientific workers from Cambridge and Oxford are reading papers on very-low temperature research, in which subject the president of the congress, Dr. W. H. Keesom, of Leyden, is a leading authority. The Food Investigation Board has also sent representatives who are contributing reports on food research. Refrigeration is such an important factor in everyday life nowadays, not only in relation to food supply but also as an auxiliary process in many industries, that the two hundred papers presented to the Congress barely exhaust the many phases of this modern branch of engineering development. The International Institute promoting this series of congresses is established under Government convention.

\section{War and Populations}

IN a discussion of war and over-population (Current History, March 1936), Prof. Raymond Pearl states that the aggressor in every major war in recent times has given the need for more room for his people as the primary motive. The land surface of the earth is some $52,000,000$ square miles, about one fourth of which is arid or semi-arid, while lakes and mountains still further reduce the cultivable land on which more than 2,000 million people have to dwell. An equal distribution would give each individual about sixteen acres, but probably little more than half would be available for production. The United States census for 1930 showed a population density of 40.6 per square mile-very close to the world average. Europe has 92 per square mile, Asia 76, North America 19-20, South America and Africa about 12, Australia and Oceania only 3. Among countries of the world, China stands seventh and India fifteenth in density of population. The province of Kiangsu alone, having 897 persons per square mile, has a greater population density than Belgium, while Bermuda has 1,462 per square mile. India has 195, about the same as France, but large areas of jungle and desert increase the population density of the rest. Urbanisation, however, leads to greater local densities in the West than the East. Nevertheless, highly industrialised countries can induce few of their people to emigrate to colonies. Up to 1914, Italy had placed only 8,000 Italians in her African colonies, and Germany only 24,000 Germans in her colonial empire. Pearl estimates that the British, Russian, French and American "Empires" control 57 per cent of the earth's land surface; but concludes that the conquest of these lands by other nations would not benefit the human race, while war would impoverish all the nations involved.

\section{Industrial Prospecting}

The U.S. National Research Council (Washington, D.C.) has reprinted a lecture entitled "Industrial Prospecting" which was delivered before the Founder Societies of Engineers by Mr. C. F. Kettering, chairman of the Division of Engineering and Industrial Research of the National Research Council. Mr. Kettering argues that scientific advancement has not outpaced social and economic advancement, but that, on the contrary, scientific development is $15-20$ years behind social and economic development. More research is needed, since research is a way of finding out what is to be done when it is impossible to keep on doing what is being done now. New industries need to be developed in order to provide more jobs. Research is industrial prospecting, and one reason why it has not been more used is that the wrong kind of book-keeping has been followed. In manufacturing, detailed costs must be determined and each individual part must be charged with the appropriate overheads, material, processing, distribution and advertising costs; but research is not manufacturing since there is nothing to sell but ideas. In industrial prospecting each individual project cannot be expected to show a profit at the end of a set time; but taking a large number of projects over a long period of time, if the results show progress it is worth carrying on; if they do not, it ought to be cut out. Industry has been criticised for having too large a capacity, but there cannot be too large a capacity until everyone has the things he needs and wants. What should really be said is that there are too few products for the factories to make. To-day new things are needed, and we have not exhausted even a small percentage of our ability to make improvements or further developments, or to increase the utility of a product. 